\title{
Correction to: Evaluating the protective potency of Acacia hydaspica R. Parker on histological and biochemical changes induced by Cisplatin in the cardiac tissue of rats
}

Tayyaba Afsar ${ }^{1,2^{*}}$, Suhail Razak ${ }^{2^{*}}$, Ali Almajwal ${ }^{2}$, Maria Shabbir ${ }^{1,3}$ and Muhammad Rashid Khan ${ }^{1}$

Correction to: BMC Complement Altern Med 19, 182 (2019)

https://doi.org/10.1186/s12906-019-2575-8

Following publication of the original article [1], the authors identified an error in their affiliations. The correct affiliations should be as follows:

Tayyaba Afsar1,2*, Suhail Razak2*, Ali Almajwal2, Maria Shabbir1,3 and Muhammad Rashid Khan1

1 Quaid I Azam Univ, Fac Biol Sci, Dept Biochem, Islamabad, Pakistan. 2 King Saud Univ, Dept Community Hlth Sci, Coll Appl Med Sci, Riyadh, Saudi Arabia.3 NUST, Atta ur Rahman Sch Appl Biosci, Islamabad, Pakistan.

\section{Author details}

'Quaid I Azam Univ, Fac Biol Sci, Dept Biochem, Islamabad, Pakistan. ${ }^{2}$ King

Saud Univ, Dept Community HIth Sci, Coll Appl Med Sci, Riyadh, Saudi

Arabia. ${ }^{3}$ NUST, Atta ur Rahman Sch Appl Biosci, Islamabad, Pakistan.

Published online: 27 October 2020

\section{Reference}

1. Afsar, et al. Evaluating the protective potency of Acacia hydaspica R. Parker on histological and biochemical changes induced by Cisplatin in the cardiac tissue of rats. BMC Complement Altern Med. 2019;19:182. https://doi. org/10.1186/s12906-019-2575-8

\footnotetext{
The original article can be found online at https://doi.org/10.1186/s12906019-2575-8.

*Correspondence: tayyaba_sona@yahoo.com; ruhail12345@yahoo.com

'Quaid I Azam Univ, Fac Biol Sci, Dept Biochem, Islamabad, Pakistan

${ }^{2}$ King Saud Univ, Dept Community HIth Sci, Coll Appl Med Sci, Riyadh, Saudi Arabia

Full list of author information is available at the end of the article
}

(c) The Author(s). 2020 Open Access This article is licensed under a Creative Commons Attribution 4.0 International License, which permits use, sharing, adaptation, distribution and reproduction in any medium or format, as long as you give appropriate credit to the original author(s) and the source, provide a link to the Creative Commons licence, and indicate if changes were made. The images or other third party material in this article are included in the article's Creative Commons licence, unless indicated otherwise in a credit line to the material. If material is not included in the article's Creative Commons licence and your intended use is not permitted by statutory regulation or exceeds the permitted use, you will need to obtain permission directly from the copyright holder. To view a copy of this licence, visit http://creativecommons.org/licenses/by/4.0/ The Creative Commons Public Domain Dedication waiver (http://creativecommons.org/publicdomain/zero/1.0/) applies to the data made available in this article, unless otherwise stated in a credit line to the data. 